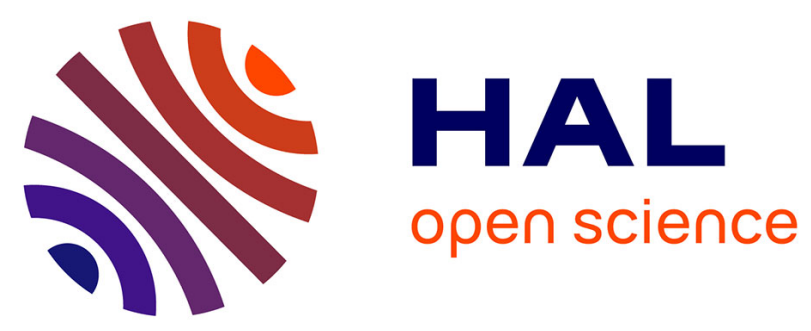

\title{
Synthesis and Structural Characterization of the Tetrakis(methimazolyl)borates Li[Bmt4] and $[\mathrm{Ru}(\mathrm{p}$-cymene)(Bmt4)][PF6]
}

Kerstin Kunz, Michael Bolte, Matthias Wagner, Hans-Wolfram Lerner

\section{To cite this version:}

Kerstin Kunz, Michael Bolte, Matthias Wagner, Hans-Wolfram Lerner. Synthesis and Structural Characterization of the Tetrakis(methimazolyl)borates $\mathrm{Li}[\mathrm{Bmt} 4]$ and $[\mathrm{Ru}(\mathrm{p}$-cymene)(Bmt4)][PF6]. Journal of Inorganic and General Chemistry / Zeitschrift für anorganische und allgemeine Chemie, 2009, 635 (11), pp.1580. 10.1002/zaac.200900116 . hal-00479612

\section{HAL Id: hal-00479612 https://hal.science/hal-00479612}

Submitted on 1 May 2010

HAL is a multi-disciplinary open access archive for the deposit and dissemination of scientific research documents, whether they are published or not. The documents may come from teaching and research institutions in France or abroad, or from public or private research centers.
L'archive ouverte pluridisciplinaire HAL, est destinée au dépôt et à la diffusion de documents scientifiques de niveau recherche, publiés ou non, émanant des établissements d'enseignement et de recherche français ou étrangers, des laboratoires publics ou privés. 


\section{Zeitschrift für Anorganische und}

Allgemeine Chemie

\section{Synthesis and Structural Characterization of the Tetrakis(methimazolyl)borates Li[Bmt4] and [Ru(p- cymene)(Bmt4)][PF6]}

\begin{tabular}{|c|c|}
\hline Journal: & Zeitschrift für Anorganische und Allgemeine Chemie \\
\hline Manuscript ID: & zaac. 200900116 \\
\hline Wiley - Manuscript type: & Article \\
\hline $\begin{array}{r}\text { Date Submitted by the } \\
\text { Author: }\end{array}$ & 18-Feb-2009 \\
\hline Complete List of Authors: & $\begin{array}{l}\text { Kunz, Kerstin; Goethe Universitaet Frankfurt, Institut fuer } \\
\text { Anorganische Chemie } \\
\text { Bolte, Michael; Goethe Universitaet Frankfurt, Institut fuer } \\
\text { Anorganische Chemie } \\
\text { Wagner, Matthias; Goethe Universitaet Frankfurt, Institut fuer } \\
\text { Anorganische Chemie } \\
\text { Lerner, Hans-Wolfram; Goethe Universitaet Frankfurt, Institut fuer } \\
\text { Anorganische Chemie }\end{array}$ \\
\hline Keywords: & $\begin{array}{l}\text { Scorpionate, Methimazolylborate, Ruthenium, X-ray structure } \\
\text { analysis }\end{array}$ \\
\hline
\end{tabular}

\section{s) ScholarONE" \\ Manuscript Central}




\section{Synthesis and Structural Characterization of the Tetrakis(methimazolyl)borates $\mathrm{Li}\left[\mathrm{Bmt}_{4}\right]$ and $\left[\mathrm{Ru}(p\right.$-cymene $\left.)\left(\mathrm{Bmt}_{4}\right)\right]\left[\mathrm{PF}_{6}\right]$}

Kerstin Kunz, Michael Bolte, Matthias Wagner and Hans-Wolfram Lerner*

Frankfurt, Institut für Anorganische Chemie der Goethe-Universität

Received XX.YY.2008.

*Dr. Hans-Wolfram Lerner

Institut für Anorganische Chemie

Goethe-Universität

Max-von-Laue-Str. 7

D-60438 Frankfurt am Main

Fax: +49-69-79829260

E-mail: lerner@chemie.uni-frankfurt.de 


\begin{abstract}
The lithium tetrakis(methimazolyl)borate $\mathrm{Li}\left[\mathrm{Bmt}_{4}\right]$ is accessible from the reaction of $\mathrm{Li}\left[\mathrm{BH}_{4}\right]$ with four equivalents of methimazole. The crystal structure of $\mathrm{Li}\left[\mathrm{Bmt}{ }_{4}\right]$ supported by four water molecules is described. Reaction of $\mathrm{Li}\left[\mathrm{Bmt}_{4}\right]$ with $[\mathrm{Ru}(p$ cymene) $\left.\mathrm{Cl}_{2}\right]_{2}$ and subsequent treatment with $\mathrm{NH}_{4} \mathrm{PF}_{6}$ in $\mathrm{CH}_{3} \mathrm{CN}$ results in the formation of the complex $\left[\mathrm{Ru}(p\right.$-cymene $\left.)\left(\mathrm{Bmt}_{4}\right)\right]\left[\mathrm{PF}_{6}\right]$. In addition, we report the result of the $\mathrm{X}$-ray structure analysis of the chiral $\mathrm{Ru}$ complex $\left[\mathrm{Ru}(p\right.$-cymene $\left.)\left(\mathrm{Bmt}_{4}\right)\right]\left[\mathrm{PF}_{6}\right]$.
\end{abstract}

Keywords: Scorpionate; Methimazolylborate; Ruthenium; X-ray structure analysis 


\section{Introduction}

Multidentate ligand systems have attracted considerable interest in the last decades [1, 2]. As mentioned in Figure 1, the "classical" tetradentate ligand systems $\mathrm{E}\left(\mathrm{CH}_{2} \mathrm{D}\right)_{4}(\mathrm{E}=\mathrm{C}, \mathrm{Si}$, $\mathrm{Sn} ; \mathrm{D}=\mathrm{OR}, \mathrm{SR}, \mathrm{NR}_{2}, \mathrm{PR}_{2}$ ) can coordinate in different modes: (i) in a ditopic monodentate tripodate (A), (ii) in a ditopic bidentate-chelating (B), (iii) in a tritopic bis-monodentate bidentate-chelating (C), and (iv) in a tetratopic monodentate mode (D).

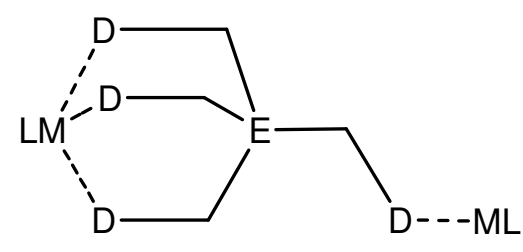

A

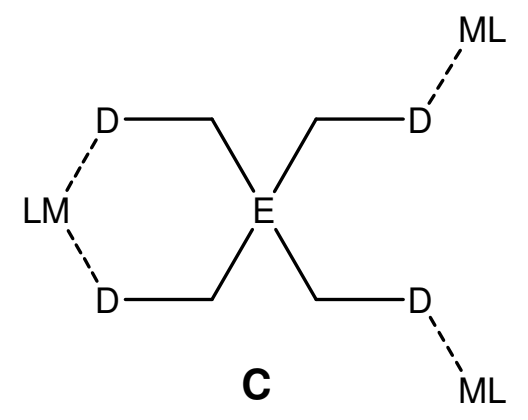

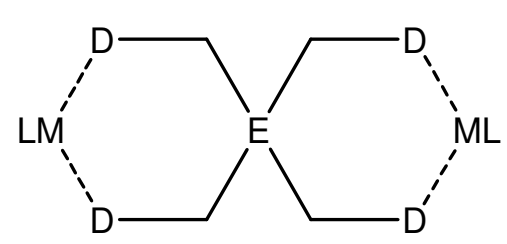

B

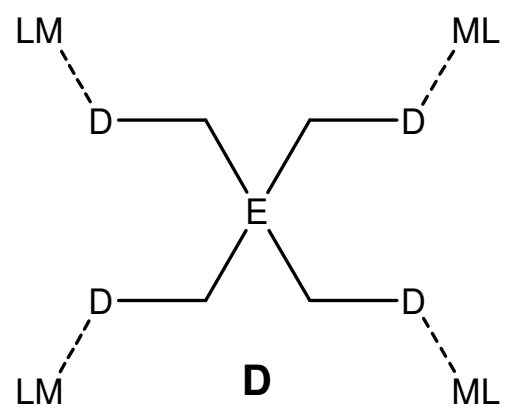

A modification of "classical" chelating ligand systems $\mathrm{RE}\left(\mathrm{CH}_{2} \mathrm{D}\right)_{3}$ and $\mathrm{E}\left(\mathrm{CH}_{2} \mathrm{D}\right)_{4}(\mathrm{E}=\mathrm{C}$, $\mathrm{Si}, \mathrm{Sn} ; \mathrm{D}=\mathrm{OR}, \mathrm{SR}, \mathrm{NR}_{2}, \mathrm{PR}_{2}$ ) with "podand topology" can be achieved by implementing 
group 13 elements as ligand centers $\mathrm{E}(\mathrm{e} . \mathrm{g} . \mathrm{E}=\mathrm{B})$ and heterocycles (e.g. pyrazole $=$ pz) as their chelating donors. Due to the Coulomb attraction between ligand and cation, very stable complexes will be formed thereby. Prominent examples of this class of ligands are the pyrazolylborates (scorpionates) $\left[\mathrm{R}_{n} \mathrm{Bpz}_{4-n}\right]^{-}(\mathrm{R}=\mathrm{H}$, alkyl, aryl; $\mathrm{n}=2,1,0 ; \mathrm{pz}=$ pyrazolyl) which have found applications in a wide range of chemistry, from modelling the active site of metaloenzymes, through analytical chemistry and organic synthesis to catalysis and materials science [3]. 


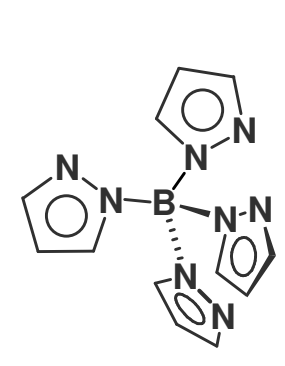

1
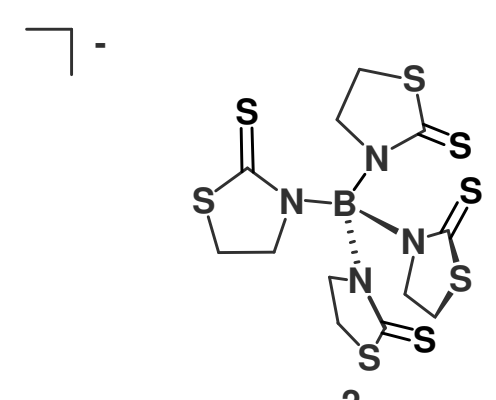

2

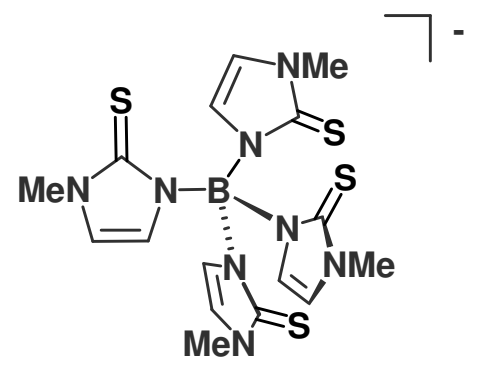

3

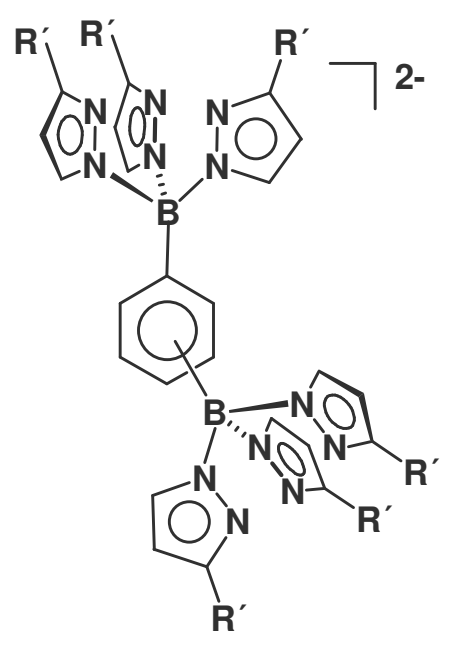

4

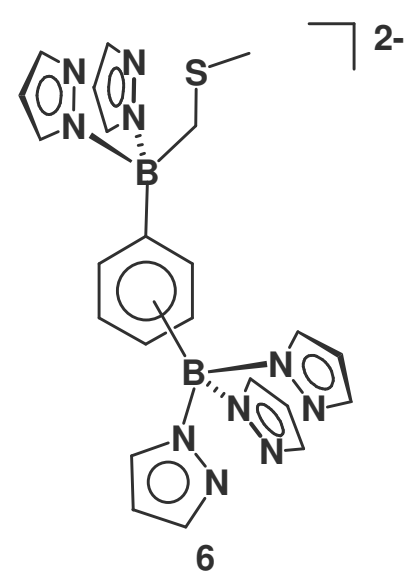

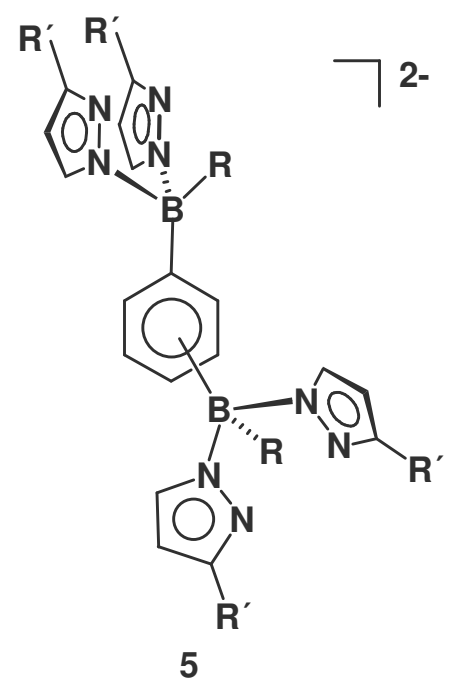

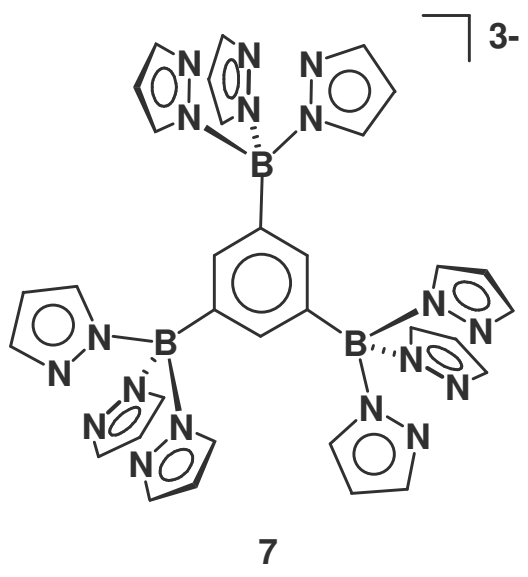


In 1967 Trofimenko reported the synthesis of a tetradentate scorpionate, the tetrakis(pyrazolyl)borate 1 (Figure 2) [4]. More than 30 years later, in 2004, a sulfur analogue of $\mathbf{1}$, the tetrakis(2-mercaptothiazolyl)borate $\mathbf{2}$, was synthesized for the first time by Silva and coworkers [5]. The synthesis was achieved from potassiumborohydride $\left.\mathrm{K}_{\left[\mathrm{BH}_{4}\right]}\right]$ and 2-mercaptothiazole. However, the preparation of the first hydrotris(methimazolyl)borate $\mathrm{M}\left[\mathrm{HBmt}_{3}\right]$, a tridentate ligand with sulfur donor, was reported earlier in 1996 by Reglinski and coworkers [6]. In contrast to pyrazolyl based scorpionates, which usually form six-membered $\mathrm{B}\left(\mathrm{N}_{2}\right)_{2} \mathrm{M}$-rings in solid state, the structural motif in soft analogues of the pyrazolylborates, the mercaptoimidazolylborates, is generally an eight-membered $\mathrm{B}(\mathrm{NCS})_{2} \mathrm{M}$-heterocycle. Normally, $\mathrm{S}, \mathrm{N}$ borate ligands such as tetrakis(2-mercaptothiazolyl)borate 2 [5] or hydrotris(methimazolyl)borate $\mathrm{Na}\left[\mathrm{HBmt}_{3}\right.$ ] [6] are softer than the pyrazolyl analogues and as such are more useful to be used as supporting ligands with soft transition metals.

In previous studies we had described the synthesis and structural characterization of several di- and tritopic ligands with a phenylene linker 4, 5, 6, and 7, as shown in Figure 2 [7, 8, 9, 10]. Now we are interested in mononuclear soft ligand systems with binding modes $\mathbf{A}$ and B, as depicted in Figure 1. Recently, we have synthesized and characterized the soft ligands $\mathrm{Sn}\left(\mathrm{CH}_{2} \mathrm{SMe}\right)_{4}$ and $\mathrm{Sn}\left(\mathrm{CH}_{2} \mathrm{PPh}_{2}\right)_{4}[2]$. However, the solid-state structure of the coordination polymer $\left\{\mathrm{Zn}\left[\mathrm{Sn}\left(\mathrm{CH}_{2} \mathrm{SMe}\right)_{4}\right]_{0.5} \mathrm{Cl}_{2}\right\}_{n}$ features $\mathrm{Zn}$ centers which are coordinated by the 
tetradentate ligand $\mathrm{Sn}\left(\mathrm{CH}_{2} \mathrm{SCH}_{3}\right)_{4}$ in the tritopic bis-monodentate bidentate-chelating mode C [2].

Herein we report the synthesis of the tetradentate tetrakis(methimazolyl)borate ligand $\left[\mathrm{Bmt}_{4}\right]^{-}$(3) and its coordination behavior. In addition, we describe the result of the X-ray structure analysis of $\left[\mathrm{Li}\left(\mathrm{H}_{2} \mathrm{O}\right)_{4}\right]\left[\mathrm{Bmt}_{4}\right]\left\{\left[\mathrm{Li}\left(\mathrm{H}_{2} \mathrm{O}\right)_{4}\right][3]\right\}$ and the synthesis of the complex $\left[\mathrm{Ru}(p\right.$-cymene $\left.)\left(\mathrm{Bmt}_{4}\right)\right]\left[\mathrm{PF}_{6}\right]\left\{\mathbf{8}\left[\mathrm{PF}_{6}\right]\right\}$ which can be obtained by reaction of $\mathrm{Li}[3]$ with $\left[\mathrm{Ru}(p \text {-cymene }) \mathrm{Cl}_{2}\right]_{2}$ in the presence of $\mathrm{NH}_{4} \mathrm{PF}_{6}$ in $\mathrm{CH}_{3} \mathrm{CN}$.

\section{Results and discussion}

Recently Bailey and coworkers have reported the synthesis of the ligands $[\mathrm{B}(\mathrm{N}-$ methylimidazolyl $\left.)(\mathrm{mt})_{3}\right]^{-} \quad[11,12]$. Now we were able to prepare the lithium tetrakis(methimazolyl)borate $\mathrm{Li}[3]$ in the melt by reaction of one equivalent of $\mathrm{Li}\left[\mathrm{BH}_{4}\right]$ with four equivalents of methimazole, as shown in Scheme 1. In contrast to the preparation of $\mathrm{Li}[3]$ the syntheses of hydrotris(methimazolyl)borates $\mathrm{M}\left[\mathrm{HBmt}_{3}\right](\mathrm{M}=\mathrm{Li}, \mathrm{Na}, \mathrm{K})$ and dihydrobis(methimazolyl)borate $\mathrm{M}\left[\mathrm{H}_{2} \mathrm{Bmt}_{2}\right]$ were achieved at lower temperatures by the reaction of $\mathrm{M}\left[\mathrm{BH}_{4}\right](\mathrm{M}=\mathrm{Li}, \mathrm{Na}, \mathrm{K})$ with 3 or 2 equivalents of methimazole $[6,13,14,15]$. Single crystals of $\left[\mathrm{Li}\left(\mathrm{H}_{2} \mathrm{O}\right)_{4}\right][3]$ suitable for X-ray diffraction were obtained from a solution 
of methanol and water at room temperature. The colorless methimazolyl borate $\mathrm{Li}[3]$ is stable against air and moisture. However, Li[3] can easily be transformed to the corresponding transition metal complexes by salt metathesis.

\section{--- Scheme 1---}

First of all the $\mathrm{Ru}(\mathrm{II})$ complex $\mathbf{8}[\mathrm{Cl}]$ was generated by the reaction of $\mathrm{Li}[3]$ with $[\mathrm{Ru}(p$ cymene) $\left.\mathrm{Cl}_{2}\right]_{2}$ in $\mathrm{CH}_{3} \mathrm{CN}$ (Scheme 1). Subsequent treatment with $\mathrm{NH}_{4} \mathrm{PF}_{6}$ led to the formation of the corresponding complex $\mathbf{8}\left[\mathrm{PF}_{6}\right]$. Recrystallization from methylene chloride yielded large red single crystals of $\mathbf{8}\left[\mathrm{PF}_{6}\right]$ suitable for X-ray diffraction.

The tetrakis(methimazolyl)borate $\left[\mathrm{Li}\left(\mathrm{H}_{2} \mathrm{O}\right)_{4}\right][3]$ crystallizes in the triclinic space group $P-1$ with four molecules in the asymmetric unit (Figures 3 and 4). The Li cation in $\left[\mathrm{Li}\left(\mathrm{H}_{2} \mathrm{O}\right)_{4}\right][3]$ is coordinated by four molecules of water. The angles around the boron atom are with $109.5(1)^{\circ}$ very close to the ideal tetrahedral angle $\left(109.5^{\circ}\right)$. As is to be expected for the donor-supported lithium atoms in $\left[\mathrm{Li}\left(\mathrm{H}_{2} \mathrm{O}\right)_{4}\right][3]$, no short $\mathrm{Li}-\mathrm{S}$ contacts are found in this structure. In consequence the Li-S-distance of $4.506-9.171 \AA$ in the solvent separated ion pair $\left[\mathrm{Li}\left(\mathrm{H}_{2} \mathrm{O}\right)_{4}\right][3]$ is significantly longer than the sum of the atomic radii.

\section{--- Figure 3 and 4---}


The ruthenium complex $\mathbf{8}\left[\mathrm{PF}_{6}\right]$ crystallizes together with one molecule of methylene chloride (Figure 5). Due to the chiral nature tetrakis(methimazolyl)borates exist as a pair of two mirror-image forms. As expected the unit cell of $\mathbf{8}\left[\mathrm{PF}_{6}\right]$ contains two molecules one of each enantiomer (Figure 6). The structural parameters of the tetrakis(methimazolyl)borate ligand in $\mathbf{8}\left[\mathrm{PF}_{6}\right]$ are comparable to those of the anion in $\left[\mathrm{Li}\left(\mathrm{H}_{2} \mathrm{O}\right)_{4}\right][3]$. The $\mathrm{Ru}$ atom which is coordinated by three sulfur atoms of the tetrakis(methimazolyl)borate ligand [Ru-S distances: $2.4253(10)-2.4601(10) \AA]$, form relatively short contacts to the carbon atoms of the cymene ligand. The Ru atom displays Ru-C distances of 2.201(4) $-2.246(4) \AA$ to the carbon atoms of the cymene rings. This is, in essence, the same situation as in $[\mathrm{Ru}(p$ cymene $)\left(\mathrm{B}(\mathrm{N}-\right.$-methylimidazolyl $\left.\left.)(\mathrm{mt})_{3}\right)\right][\mathrm{Cl}][11]$, where the anion has been exchanged.

\section{--- Figure 5 and 6 ---}


--- Table 1 ---

\section{Conclusion}

The lithium tetrakis(methimazolyl)borate $\mathrm{Li}[3]$ is accessible from the reaction of $\mathrm{Li}\left[\mathrm{BH}_{4}\right]$ with four equivalents of methimazole in the melt. X-ray quality crystals of $\mathrm{Li}[3]$ supported by four water molecules were obtained from a solution of methanol and water at ambient temperature. Reaction of $\mathrm{Li}[3]$ with $\left[\mathrm{Ru}(p \text {-cymene }) \mathrm{Cl}_{2}\right]_{2}$ and subsequent treatment with $\mathrm{NH}_{4} \mathrm{PF}_{6}$ in $\mathrm{CH}_{3} \mathrm{CN}$ results in the formation of the complex $8\left[\mathrm{PF}_{6}\right]$. In addition, we report the result of the $\mathrm{X}$-ray structure analysis of the chiral $\mathrm{Ru}$ complex $\mathbf{8}\left[\mathrm{PF}_{6}\right]$. As expected the unit cell of $\mathbf{8}\left[\mathrm{PF}_{6}\right]$ contains two molecules one of each enantiomer.

\section{Experimental Section}

General Remarks: All experiments were carried out under dry argon or nitrogen using standard Schlenk and glove box techniques. Solvents were distilled from Na/benzophenone (toluene), $\mathrm{Na} / \mathrm{Pb}$ alloy (pentane), $\mathrm{CaH}_{2}\left(\mathrm{CH}_{2} \mathrm{Cl}_{2}, \mathrm{CHCl}_{3}\right)$ and molecular sieve $\left(\mathrm{CH}_{3} \mathrm{CN}\right)$ under a dry argon atmosphere prior to use. Starting materials were purchased from commercial sources and used without further purification. NMR: Bruker Avance 300. 
Chemical shifts are referenced to residual solvent signals $\left({ }^{1} \mathrm{H},{ }^{13} \mathrm{C}\right)$ or external $\mathrm{BF}_{3} \cdot \mathrm{Et}_{2} \mathrm{O}$ $\left({ }^{11} \mathrm{~B}\right)$. Abbreviations: $\mathrm{s}=$ singlet, $\mathrm{d}=$ doublet, sept $=$ septet, $\mathrm{n} . \mathrm{r} .=$ multiplet expected in the ${ }^{1}$ H NMR spectrum but not resolved, n.o. = signal not observed, br $=$ broad. The free methimazolyl substituent is denoted with an asterisk $\left(\mathrm{mt}^{*}\right)$.

Synthesis of $\mathbf{~ L i}[3]: \mathrm{LiBH}_{4}$ in THF (2.33 ml, $\left.4.66 \mathrm{mmol}, 2 \mathrm{~mol} / \mathrm{l}\right)$ and methimazole $(2.18 \mathrm{~g}$, $19.09 \mathrm{mmol}$ ) were put together and the solvent was evaporated in vacuo. The two colorless solids were heated up $(1 \mathrm{~h})$ to $200^{\circ} \mathrm{C}$ until they began to turn light yellow. $25 \mathrm{~mL}$ of toluene were added and the suspension was refluxed for 11 hours. The colorless precipitate was filtered off and washed one time with $\mathrm{CHCl}_{3}(10 \mathrm{~mL})$. The solid was suspended in $10 \mathrm{~mL}$ $\mathrm{H}_{2} \mathrm{O}$ and centrifuged. The supernatant was discarded and the solid was washed with pentane $(5 \mathrm{~mL})$ and dried in vacuo. Colorless crystals of $\left[\mathrm{Li}\left(\mathrm{H}_{2} \mathrm{O}\right)_{4}\right][3]$ were formed at room temperature by evaporation of a $\mathrm{MeOH} / \mathrm{H}_{2} \mathrm{O}$ (1:1) solution. Yield: $0.76 \mathrm{~g} \mathrm{(30 \% ).}$

${ }^{1} \mathbf{H}$ NMR (300 MHz, [D 6 ]DMSO, $\left.297.3 \mathrm{~K}\right): \delta 3.33(\mathrm{~s}, 12 \mathrm{H}, \mathrm{NMe}), 6.66,6.81(1 \times \mathrm{d}, 1 \times$ n.r., $\left.2 \times 4 \mathrm{H},{ }^{3} J_{\mathrm{HH}}=2.4 \mathrm{~Hz}, \mathrm{CH}\right) .-{ }^{13} \mathbf{C}\left\{{ }^{1} \mathbf{H}\right\}$ NMR $\left(75.5 \mathrm{MHz},\left[\mathrm{D}_{6}\right] \mathrm{DMSO}, 298.7 \mathrm{~K}\right): \delta$ 34.0 (NMe), 115.3, $124.3(\mathrm{CH}), 164.0$ (CS), n.o. (CB). $-{ }^{\mathbf{1 1}} \mathbf{B}\left\{{ }^{\mathbf{1}} \mathbf{H}\right\} \mathbf{N M R}(96.3 \mathrm{MHz}$, [D $]$ DMSO, $297.1 \mathrm{~K}): \delta 0.5\left(h_{1 / 2}=9 \mathrm{~Hz}\right)$. Anal. Calcd for $\mathrm{C}_{16} \mathrm{H}_{20} \mathrm{BLiN}_{8} \mathrm{~S}_{4}(470.40) \times 4$ $\mathrm{H}_{2} \mathrm{O}$ (18.02): C, 35.43; H, 5.20; N, 20.66. Found: C, 35.77; H, 5.31; N, 20.18. MS (ESI'): $m / z(\%)=463.2(100.00) 464.2(26.49) 462.1(22.31) 465.2(20.04) 466.1$ (4.48) 467.1 (1.69) $\left[\mathrm{Bmt}_{4}\right]^{-}$, calcd for $\left[\mathrm{Bmt}_{4}\right]^{-} 463.08$ (100.0) 464.08 (29.1) 462.08 (25.6) 465.08 (22.4) 466.08 (4.9) 467.07 (1.4). 
Synthesis of $8\left[\mathbf{P F}_{\mathbf{6}}\right]:\left[\mathrm{Ru}(p \text {-cymene }) \mathrm{Cl}_{2}\right]_{2}(0.23 \mathrm{~g}, 0.38 \mathrm{mmol})$ was stirred in $35 \mathrm{~mL}$ of $\mathrm{CH}_{3} \mathrm{CN}$ for $1 \mathrm{~h}$. [ $\left.\mathrm{Li}\left(\mathrm{H}_{2} \mathrm{O}\right)_{4}\right][3](0.40 \mathrm{~g}, 0.74 \mathrm{mmol})$ was added and the reaction mixture was stirred for $1 \mathrm{~h}$ at $60^{\circ} \mathrm{C}$. The solvent was evaporated in vacuo and the residue was resolved in $50 \mathrm{~mL}$ of EtOH. To the solution was added $\mathrm{NH}_{4} \mathrm{PF}_{6}(0.12 \mathrm{~g}, 0.74 \mathrm{mmol})$ and it was stirred for $2 \mathrm{~d}$ at room temperature. The red-brown precipitate was filtered off, washed five times with $\mathrm{EtOH}(5 \mathrm{~mL})$ and dried in vacuo. Yield: $0.18 \mathrm{~g}(29 \%)$. Single crystals of $8\left[\mathrm{PF}_{6}\right]$ were formed upon slow diffusion of $\mathbf{8}\left[\mathrm{PF}_{6}\right]$ in $\mathrm{CH}_{2} \mathrm{Cl}_{2}$ in pentane.

${ }^{1} \mathbf{H}$ NMR $\left(300 \mathrm{MHz}, \mathrm{CD}_{2} \mathrm{Cl}_{2}, 299.6 \mathrm{~K}\right): \delta 1.21,1.23\left(2 \times \mathrm{d}, 2 \times 3 \mathrm{H},{ }^{3} J_{\mathrm{HH}}=4.8 \mathrm{~Hz}, \mathrm{CH}_{3^{-}}\right.$ ${ }^{i} \mathrm{Pr}$ ), 2.21 (s, 3H, $\mathrm{CH}_{3}$ ), 2.95 (sept, $1 \mathrm{H}, \mathrm{CH}^{-}{ }^{i} \mathrm{Pr}$ ), 3.52 (s, 3H, $\mathrm{NMe}^{*}$ ), 3.69 (s, 9H, NMe), 5.29-5.41 (n.r., 4H, Ar-H), $6.86\left(\mathrm{~d}, 1 \mathrm{H},{ }^{3} J_{\mathrm{HH}}=2.7 \mathrm{~Hz}, \mathrm{CH}^{*}\right), 6.92\left(\mathrm{~d}, 3 \mathrm{H},{ }^{3} J_{\mathrm{HH}}=2.4 \mathrm{~Hz}\right.$, $\mathrm{CH}), 6.99\left(\mathrm{~d}, 1 \mathrm{H},{ }^{3} \mathrm{~J}_{\mathrm{HH}}=2.4 \mathrm{~Hz}, \mathrm{CH}^{*}\right), 7.08(\mathrm{br}, 3 \mathrm{H}, \mathrm{CH}) \cdot-{ }^{13} \mathbf{C}\left\{{ }^{1} \mathbf{H}\right\} \mathbf{N M R}(100.6 \mathrm{MHz}$, $\left.\mathrm{CD}_{2} \mathrm{Cl}_{2}, 298.0 \mathrm{~K}\right): \delta 18.9\left(\mathrm{CH}_{3}\right), 22.5,22.7\left(\mathrm{CH}_{3}{ }^{i} \mathrm{Pr}\right), 30.8 .(\mathrm{CH}), 35.5\left(\mathrm{NMe}^{*}\right), 35.8$ (NMe), 83.7, 84.9, 85.5, 85.6 (Ar-C), 101.6, 106.8 (Ar-iC), 119.6, $119.9\left(\mathrm{CH}^{*}\right), 120.9$, $124.3(\mathrm{CH})$, n.o. (CS), n.o. (CB). $-{ }^{11} \mathbf{B}\left\{{ }^{1} \mathbf{H}\right\}$ NMR (96.3 MHz, $\left.\mathrm{CD}_{2} \mathrm{Cl}_{2}, 299.5 \mathrm{~K}\right): \delta 0.7\left(h_{1 / 2}\right.$ $=10 \mathrm{~Hz}$ ). Anal. Calcd for $\mathrm{C}_{26} \mathrm{H}_{34} \mathrm{BF}_{6} \mathrm{~N}_{8} \mathrm{PRuS}_{4}$ (843.71): C, 37.01; H, 4.06; N, 13.28. Found: C, 36.80; H, 4.10; N, 13.01. MS $\left(\mathrm{ESI}^{+}\right): \mathrm{m} / z(\%)=698.6(100.00) 699.4(90.52)$ 697.6 (77.94) $700.5(68.55) 701.3(55.68) 702.4(20.79)\left[\mathrm{Bmt}_{4}\right]^{-}$, calcd for $\left[\mathrm{Bmt}_{4}\right]^{-} 699.09$ (100.0) 698.09 (76.9) 701.09 (65.5) 697.09 (52.2) 700.09 (50.7) 696.09 (39.9) (22.9) 695.09 (14.6) 693.09 (13.3) 703.09 (12.4) 694.10 (5.5) 692.1 (3.0) 704.09 (3.0). 
X-ray structure determination. Data collection: Stoe-IPDS-II diffractometer, graphite monochromated Mo $\mathrm{K}_{\alpha}$ radiation; $T=173 \mathrm{~K}$. Empirical absorption correction using MULABS [16], structure solution by direct methods [17], structure refinement by fullmatrix least-squares on $F^{2}$ with SHELXL-97 [18]. Hydrogen atoms were placed on ideal positions and refined with fixed isotropic displacement parameters using a riding model. Crystallographic data (excluding structure factors) for the structures reported in this paper have been deposited with the Cambridge Crystallographic Data Centre as supplementary publication nos. CCDC $711110\left\{\left[\mathrm{Li}\left(\mathrm{H}_{2} \mathrm{O}\right)_{4}\right][3]\right\}$ and CCDC $711111\left\{\mathbf{8}\left[\mathrm{PF}_{6}\right]\right\}$. Copies of the data can be obtained free of charge on application to CCDC, 12 Union Road, Cambridge CB2 1EZ (Telefax : +1223/336 033; e-mail: deposit@ ccdc.cam.ac.uk).

\section{References}

[1] C. Bianchini, C. Mealli, A. Meli, Stereochemistry of Organometallic and Inorganic Compounds, I. Bernal (ed.), Elsevier, Amsterdam 1986, 146.

[2] K. Ruth, M. Müller, M. Bolte, J. W. Bats, M. Wagner, H.-W. Lerner, Z. Anorg. Allg. Chem. 2007, 633, 1485-1489.

[3] S. Trofimenko, Scorpionates - The Coordination Chemistry of Polypyrazolylborate Ligands; Imperial College Press: London, 1999.

[4] S. Trofimenko, J. Am. Chem. Soc. 1967, 89, 3170.

[5] L. F. Soares, D. C. Menezes, R. M. Silva, A, C. Doriguetto, J. Ellena, Y. P. Mascarenhas, E. E. Castellano, Polyhedron 2004, 23, 205-209.

[6] M. Garner, J. Reglinski, I. Cassidy, M. D. Spicer, A. R. Kennedy, Chem. Commun., 1996, 1975-1976. 
[7] S. Bieller, F. Zhang, M. Bolte, J. W. Bats, H.-W. Lerner, M. Wagner, Organometallics 2004, 23, 2107-2113.

[8] Zhang, M. Bolte, H.-W. Lerner, M. Wagner, Organometallics 2004, 23, 5075-5080; S. Bieller, M. Bolte, H.-W. Lerner, M. Wagner, Inorg. Chem. 2005, 44, 9489-9496; F. Zhang, T. Morawitz, S. Bieller, M. Bolte, H.-W. Lerner, M. Wagner, Dalton Trans. 2007, 45944598; T. Morawitz, M. Bolte, H.-W. Lerner, M. Wagner, Z. Anorg. Allg. Chem. 2008, 634, 1409-1414, T. Morawitz, M. Bolte, H.-W. Lerner, M. Wagner, Z. Anorg. Allg. Chem. 2008, 634, 1570-1574.

[9] K. Ruth, S. Tüllmann, H. Vitze, M. Bolte, H.-W. Lerner, M. C. Holthausen, M. Wagner, Chem. Eur. J. 2008, 14, 6754-6770.

[10] T. Morawitz, F. Zhang, M. Bolte, J. W. Bats, H.-W. Lerner, M. Wagner, Organometallics 2008, 27, 5067-5074.

[11] P. J. Bailey, D. Lorono-Gonzales, C. McCormack, F. Millican, S. Parsons, R. Pfeifer, P. P. Pinho, F. Rudolphi, A. Sanchez Perucha Chem. Eur. J. 2006, 12, 5293 - 5300. [12] P. J. Bailey, C. McCormack, S. Parsons, F. Rudolphi, A. Sanchez Perucha, P. Wood, Dalton Trans. 2007, 476-480.

[13] S. Senda, Y. Ohki, T. Hirayama, D. Toda, J.-L. Chen, T. Matsumoto, H. Kawaguchi, K. Tatsum, Inorg. Chem. 2006, 45, 9914-9925.

[14] C. Kimblin, T. Hascall, G. Parkin, Inorg. Chem. 1997, 36, 5680-5681; C. Kimblin, B. M. Bridgewater, T. Hascall, G. Parkin, Dalton Trans. 2000, 891-897.

[15] A. F. Hill, G. R. Owen, A. J. P. White, D. J. Williams, Angew. Chem. 1999, 111, 2920; A. F. Hill, G. R. Owen, A. J. P. White, D. J. Williams, Angew. Chem., Int. Ed. 1999, 38, 2759. M. L. H. Green, J. Organomet. Chem. 1995, 500, 127; M. R. St.-J. Foreman, A. F. Hill, G. R. Owen, A. J. P. White, D. J. Williams, Organometallics 2003, 22, 4446; M. R. St.-J. Foreman, A. F. Hill, A. J. P. White, D. J. Williams, Organometallics 2004, 23, 913; I. R. Crossley; A. F. Hill, Organometallics 2004, 23, 5656; I. R. Crossley, M. R. St.-J. Foreman, A. F. Hill, A. J. P. White, D. J. Williams, Chem. Commun. 2005, 221; I. R. Crossley, A. F. Hill, A. C. Willis, Organometallics 2005, 24, 1062; I. R. Crossley, A. F. 
Hill, E. R. Humphrey, A. C. Willis, Organometallics, 2005, 24, 4083; I. R. Crossley, A. F. Hill, A. C. Willis, Organometallics 2006, 25, 289; I. R. Crossley, A. F. Hill, A. C. Willis, Organometallics 2007, 26, 3891; I. R. Crossley, A. F. Hill, Dalton Trans. 2008, 201; I. R. Crossley, A. F. Hill, A. C. Willis, Organometallics 2008, 27, 312; I. R. Crossley, M. R. St.J. Foreman, A. F. Hill, G. R. Owen, A. J. P. White, D. J. Williams, A. C. Willis, Organometallics 2008, 27, 381. J. S. Figueroa, J. G. Melnick, G. Parkin, Inorg. Chem. 2006, 45, 7056; K. Pang, S. M. Quan,G. Parkin, Chem. Commun. 2006, 5015; D. J. Mihalcik, J. L. White, J. M. Tanski, L. N. Zakharov, G. P. A. Yap, C. D. Incarvito, A. L. Rheingold, D. Rabinovich, Dalton Trans. 2004, 1626; R. J. Blagg, J. P. H. Charmant, N. G. Connelly, M. F. Haddow, A. G. Orpen, Chem. Commun. 2006, 2350; K. Pang, J. M. Tanski, G. Parkin, Chem. Commun. 2008, 1008.

[16] R. H. Blessing, Acta Crystallogr. Sect. A 1995, 51, 33-38.

[17] G. M. Sheldrick, Acta Crystallogr. Sect. A 1990, 46, 467.

[18] G. M. Sheldrick in SHELXL 97, Vol. University of Göttingen, Göttingen, Germany, 1997.

Figure 1 Tetradentate ligand systems for polymetallic coordination chemistry.

Figure 2 Di- and tritopic boron-based ligands.

Figure 3 Structure of $\left[\mathrm{Li}\left(\mathrm{H}_{2} \mathrm{O}\right)_{4}\right][3]$ in the crystal; thermal ellipsoids are drawn at the $50 \%$ probability level. Selected bond lengths / $\AA$ and angles / ${ }^{\circ}$ : B(1)-N(1) 1.5699(19); N(1)B(1)-N(1)\#2 108.52(14), N(1)\#1-B(1)-N(1) 109.95(7). Symmetry transformations used to 
generate equivalent atoms: $-y+3 / 4, x-1 / 4,-z+3 / 4(\# 1),-x+1,-y+1 / 2, z+0$ (\#3).

Figure 4 Crystal packing diagram of $\left[\mathrm{Li}\left(\mathrm{H}_{2} \mathrm{O}\right)_{4}\right][3]$.

Figure 5 Structure of $\mathbf{8}\left[\mathrm{PF}_{6}\right]$ in the crystal; thermal ellipsoids are drawn at the $50 \%$ probability level. Selected bond lengths / $\AA$, atom $\cdots$ atom distances / $\AA$ and angles / ${ }^{\circ}: \mathrm{B}(1)$ $\mathrm{N}(1)$ 1.547(5), B(1)-N(11) 1.556(6), B(1)-N(21) 1.576(5), B(1)-N(31) 1.573(5), C(1)-S(1) 1.730(4), C(11)-S(11) 1.734(4), C(21)-S(21) 1.731(4), Ru(1)-S(1) 2.4253(10), Ru(1)-S(11) 2.4601(10), Ru(1)-S(21) 2.4260(9), Ru(1)-COG(Cym) 1.709; N(1)-B(1)-N(11) 110.1(3), $\mathrm{N}(1)-\mathrm{B}(1)-\mathrm{N}(21)$ 114.8(3), N(1)-B(1)-N(31) 105.2(3), N(11)-B(1)-N(21) 106.9(3), N(11)B(1)-N(31) 110.4(3), N(21)-B(1)-N(31) 109.4(3), C(1)-S(1)-Ru(1) 106.14(14), C(11)$\mathrm{S}(11)-\mathrm{Ru}(1)$ 104.75(12), C(21)-S(21)-Ru(1) 111.09(13).

Figure 6 Mirror image pair of the complex cation 8. 
Scheme 1 Synthesis of lithium tetrakis(methimazolyl)borate $\left[\mathrm{Li}\left(\mathrm{H}_{2} \mathrm{O}\right)_{4}\right][3]$, and the Ruthenium para-cymene complex $8\left[\mathrm{PF}_{6}\right]$. (i) melt, (ii) toluene, (iii) $\left[\mathrm{Ru}\left(p \text {-cymene) } \mathrm{Cl}_{2}\right]_{2}\right.$, $\mathrm{CH}_{3} \mathrm{CN}$, (iv) $\mathrm{NH}_{4} \mathrm{PF}_{6}$, EtOH.

Table 1 Crystal data and refinement details for $\left[\mathrm{Li}\left(\mathrm{H}_{2} \mathrm{O}\right)_{4}\right][3]$ and $\mathbf{8}\left[\mathrm{PF}_{6}\right]$. 


\begin{tabular}{|c|c|c|}
\hline & {$\left[\mathrm{Li}\left(\mathrm{H}_{2} \mathrm{O}\right)_{4}\right][3]$} & $\mathbf{8}\left[\mathrm{PF}_{6}\right]\left(\mathrm{CH}_{2} \mathrm{Cl}_{2}\right)$ \\
\hline empirical formula & $\mathrm{C}_{16} \mathrm{H}_{28} \mathrm{BLiN}_{8} \mathrm{O}_{4} \mathrm{~S}_{4}$ & $\mathrm{C}_{27} \mathrm{H}_{36} \mathrm{BCl}_{2} \mathrm{~F}_{6} \mathrm{~N}_{8} \mathrm{PRuS}_{4}$ \\
\hline formula weight & 542.45 & 928.63 \\
\hline $\mathrm{T} / \mathrm{K}$ & $173(2)$ & $173(2)$ \\
\hline wavelenght & $\mathrm{MoK}_{\alpha}, 0.71073 \AA$ & $\mathrm{MoK}_{\alpha}, 0.71073 \AA$ \\
\hline crystal system & tetragonal & triclinic \\
\hline space group & $I 4_{1} / a$ & $P-1$ \\
\hline$a / \AA$ & $13.9830(14)$ & $11.4919(8)$ \\
\hline$b / \AA$ & $13.9830(14)$ & $13.1799(11)$ \\
\hline$c / \AA$ & $12.7265(12)$ & $13.8989(11)$ \\
\hline$\alpha /^{\circ}$ & 90 & $78.370(6)$ \\
\hline$\beta /^{\circ}$ & 90 & $71.105(6)$ \\
\hline$\gamma /{ }^{\circ}$ & 90 & $69.822(6)$ \\
\hline$V / \AA^{3}$ & $2488.3(4)$ & $1859.9(3)$ \\
\hline$Z$ & 4 & 2 \\
\hline density calculated $\mathrm{g} \mathrm{cm}^{-3}$ & 1.448 & 1.658 \\
\hline$F(000)$ & 1136 & 940 \\
\hline$\mu \mathrm{mm}^{-1}$ & 0.422 & 0.897 \\
\hline \multirow[t]{3}{*}{ index ranges } & $-16 \leq \mathrm{h} \leq 16$ & $-13 \leq \mathrm{h} \leq 13$ \\
\hline & $-14 \leq \mathrm{k} \leq 16$ & $-15 \leq \mathrm{k} \leq 15$ \\
\hline & $-15 \leq 1 \leq 15$ & $-16 \leq 1 \leq 16$ \\
\hline crystal size $/ \mathrm{mm}^{3}$ & $0.17 \times 0.17 \times 0.17$ & $0.29 \times 0.13 \times 0.09$ \\
\hline no. of reflections collected & 8253 & 18616 \\
\hline$R 1, w R 2[I>2 \sigma(I)]$ & $0.0400,0.0787$ & $0.0395,0.0930$ \\
\hline data / restraints / parameter & 1097 / 0 / 86 & $6900 / 423 / 514$ \\
\hline GOOF on $F^{2}$ & 0.982 & 1.003 \\
\hline$R 1, w R 2$ (all data) & $0.0665,0.0861$ & $0.0542,0.0984$ \\
\hline largest diff peak and hole / $\AA^{-3}$ & $0.224,-0.240$ & $0.971,-0.705$ \\
\hline
\end{tabular}




\section{Scheme 1}

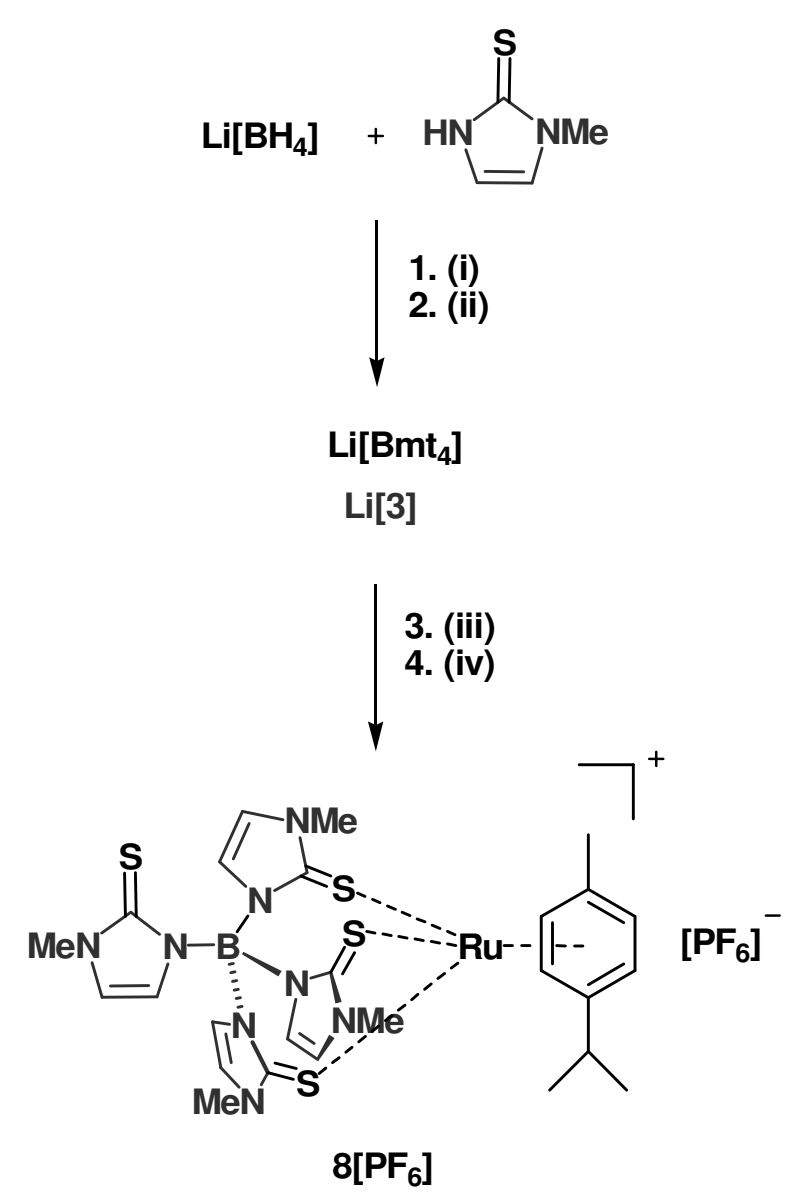




\section{Figure 1}

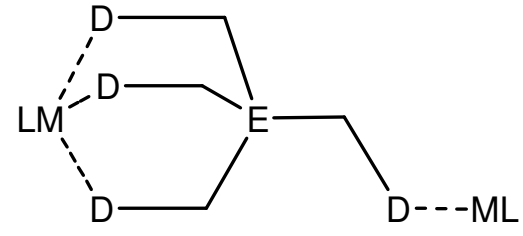

A

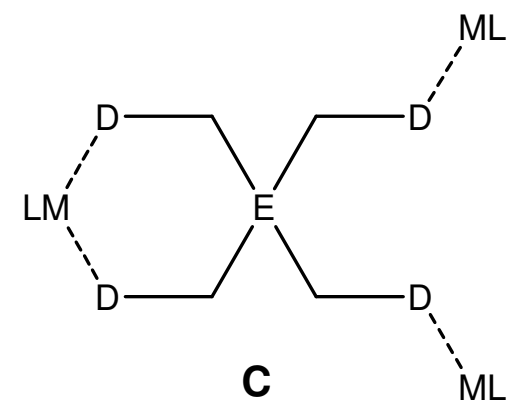

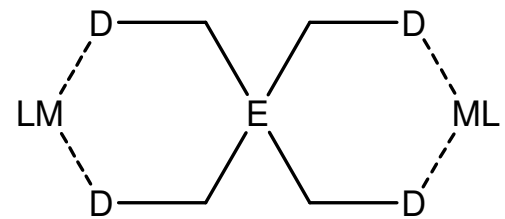

B

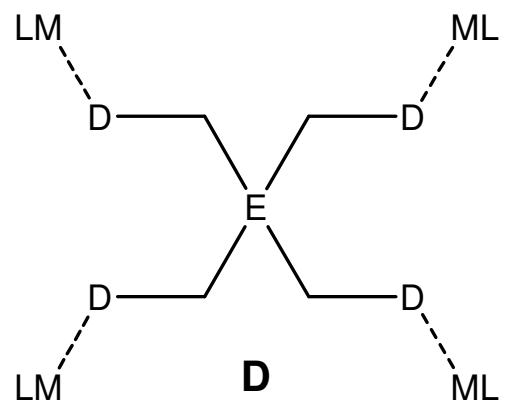


Figure 2
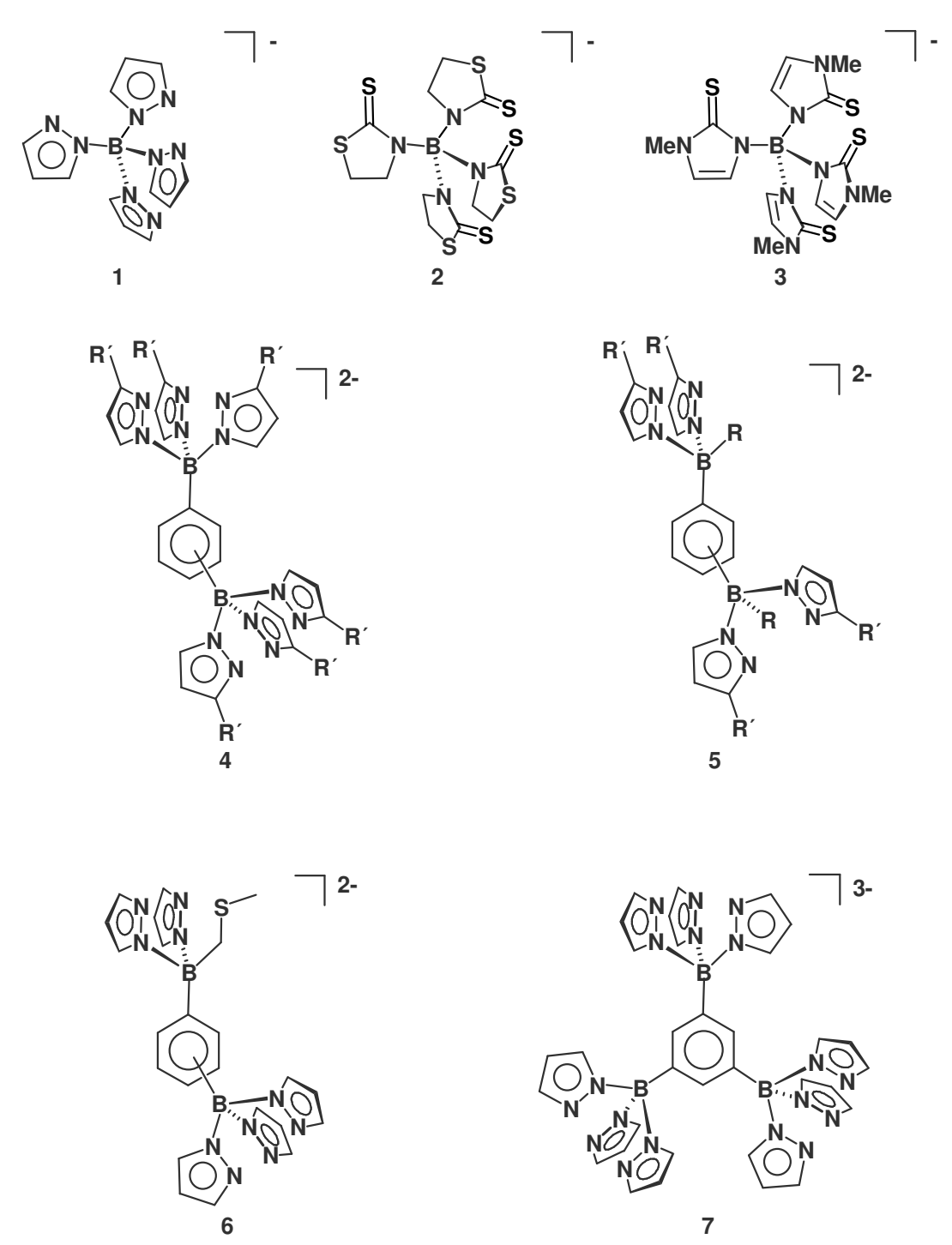

46

47

48

49

50

51

52

53

54

55

56

57

58

59

60 


\section{Figure 3}

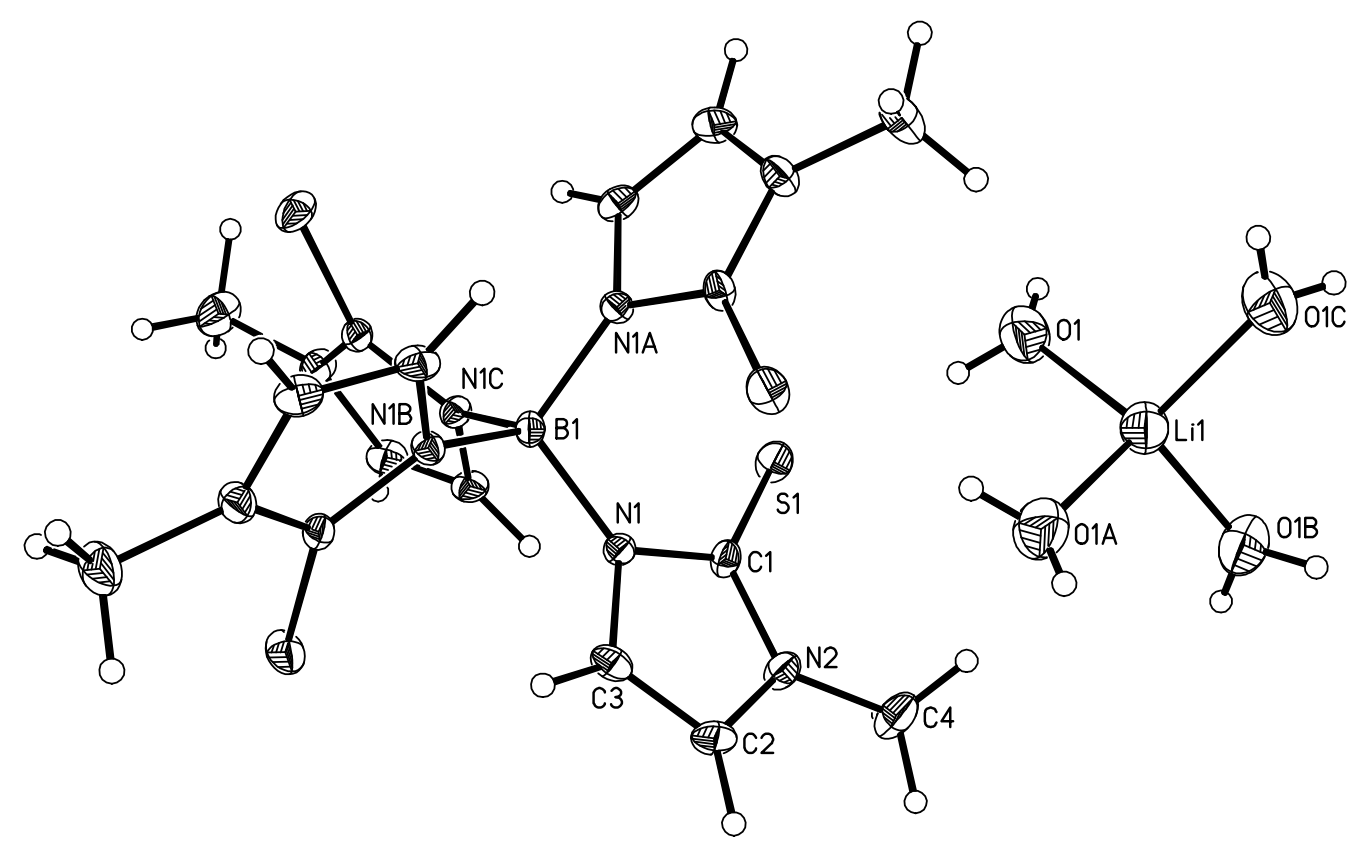




\section{Figure 4}

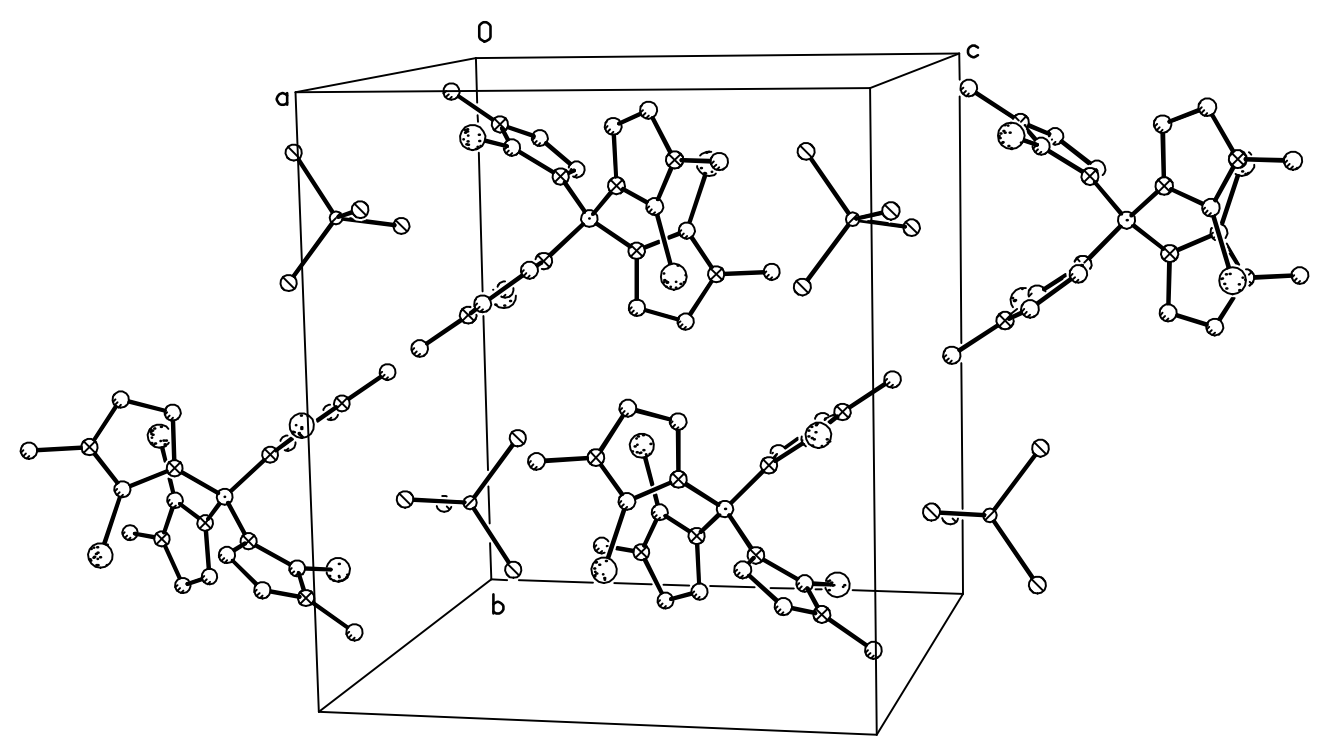




\section{Figure 5}

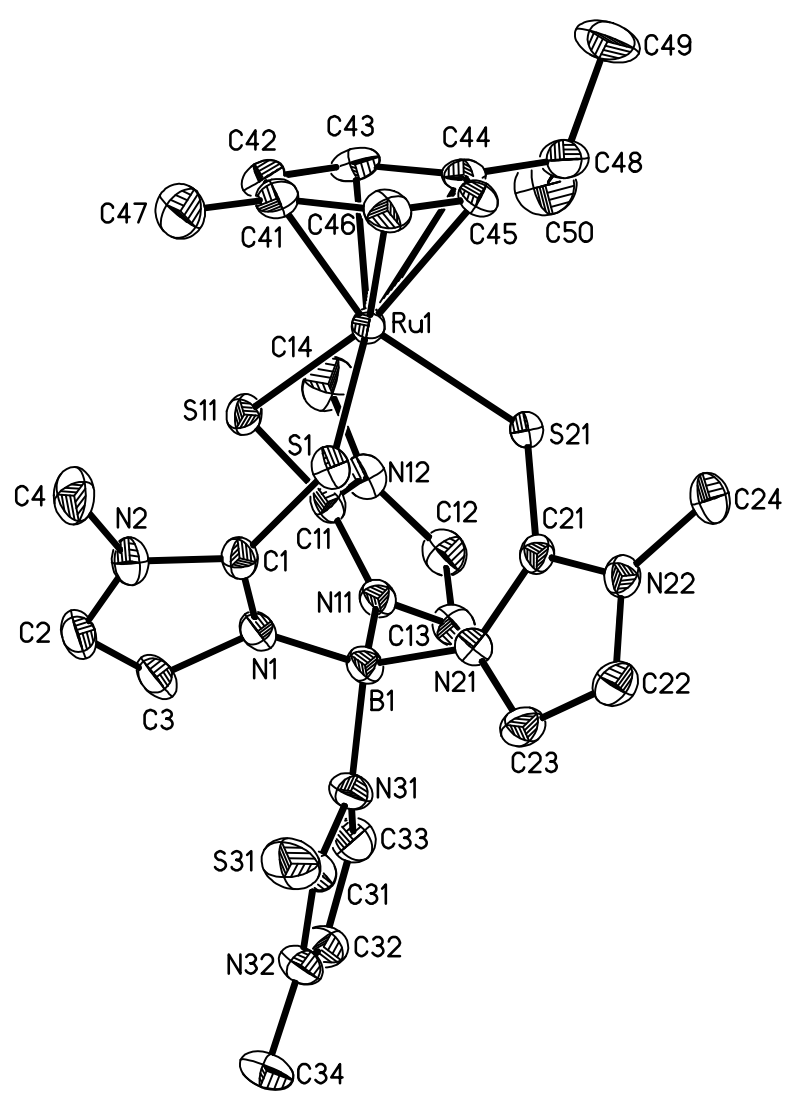


Figure 6
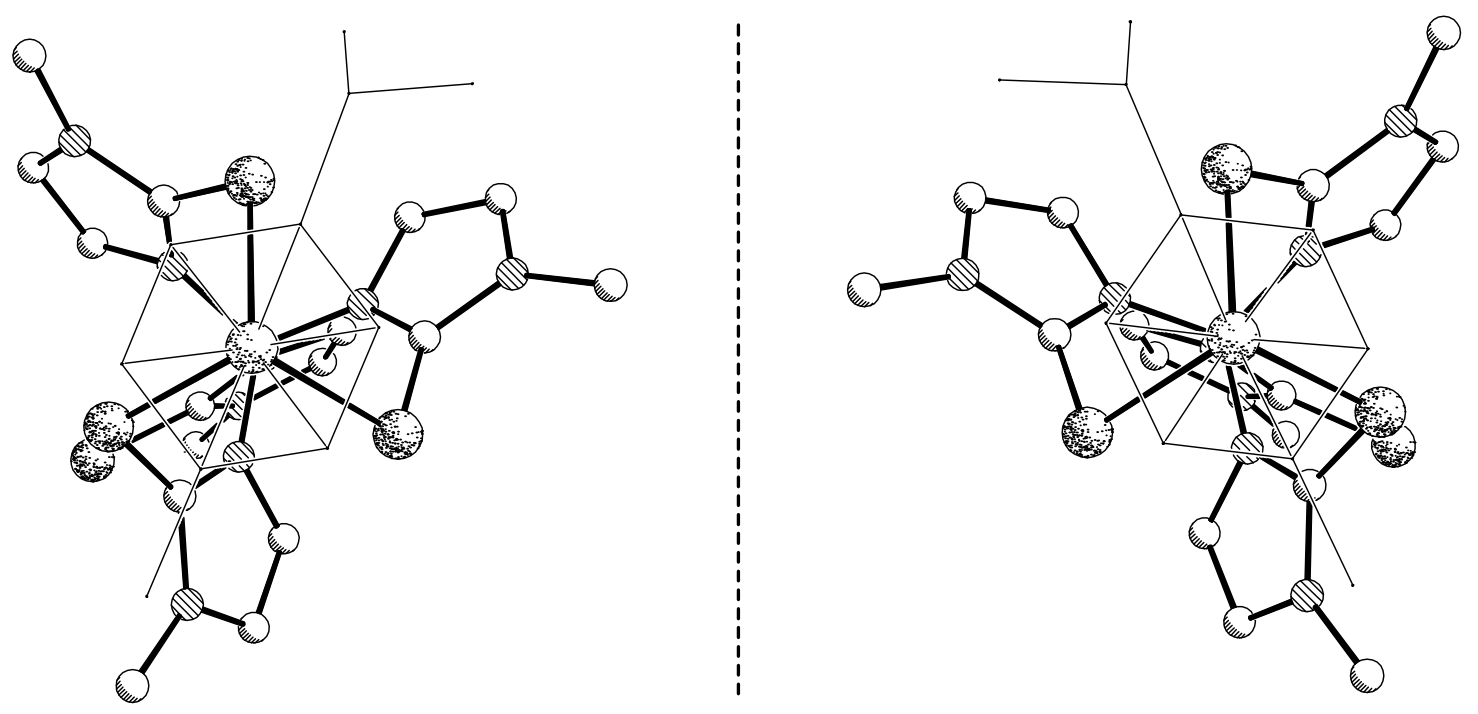

Wiley-VCH 